\title{
INCIDENCE OF CRANBERRY (Vaccinium macrocarpon Ait.) STORAGE ROT IN LATVIA
}

\author{
Lìga Vilka* and Biruta Bankina** \\ * Latvian Plant Protection Research Centre, Latvia University of Agriculture, Struktoru iela 14 a, Rīga, LATVIA, LV-1006; \\ liga.vilka@laapc.Iv \\ ** Institute of Soil and Plant Science, Latvia University of Agriculture, Lielā iela 2, Jelgava, LATVIA, LV-3001
}

Communicated by Edite Kaufmane

\begin{abstract}
The American cranberry (Vaccinium macrocarpon Ait.) is a promising perspective and marketable crop both in Latvia and foreign markets, but an important problem is fruit rot in storage. The aim of the study was to investigate the incidence of cranberry fruit rot in storage from fruit collected in different locations in Latvia. In 2007-2011, two hundred sound berries (total 1200) were randomly collected by hand along a diagonal from six different cranberry plantations from locations all over Latvia in every year. Berries were kept in plastic polyethylene (PE-LD 04) bags for four months, refrigerated at $+7^{\circ} \mathrm{C}, 83 \%$ relative humidity. At the end of each month, berries were evaluated and rotten berries were separated from the sound ones. Over the period of 2007-2011, the optimal time for cranberry storage was two months, when losses due to fruit rot reached up to $18-21 \%$. The incidence of storage rot at the end of storage period after four months (February) reached $50-88 \%$. The hot and rainy summer of 2010 significantly reduced the quality of fruit in storage, and spoilage reached on the average $88 \%$ (74-100\%) of berries in the plantations. The incidence of fruit rot varied among the surveyed cranberry growing sites. Storage rot is a problem in cranberry samples from all inspected plantations in Latvia and in the future, the incidence of fruit rot is expected to increase, because the greatest part of growers believe that American cranberries can grow in the same way as wild cranberries, without fertilisation and pesticide use.
\end{abstract}

Key words: cranberry, infection rate, shelf-life.

\section{INTRODUCTION}

In Latvia, the American cranberry (Vaccinium macrocarpon Ait.) is a promising perspective and marketable crop. American cranberry has been cultivated for fifteen years in Latvia. The cranberry fruit is used in three ways: frozen, processed into juice or other products and stored as fresh fruit. Over time, the quality of fresh fruit declines and the cost of storage increases, but this offers an opportunity to use fresh fruit for some months after harvest. Fresh fruit was observed to account for about $10 \%$ of total North American sales and only some growers stored berries until November or December (Forney, 2003; Olatinwo et al., 2004).

Along with the trend of plantations increasing in size every year in Latvia, the spread of diseases, including fruit rot, is turning into one of the most important risk factors in cranberry cultivation. In Latvia, the first investigations of fruit rot were started in 2006 (Vilka et al., 2009b). Cranberry fruit rot is a disease complex that can be caused by several pathogens in Latvia, such as: Botrytis cinerea, Allantophomopsis cytisporea, Fusiccocum putrefaciens, Phomopsis vaccinii, Coleophoma empetri, Phyllosticta elongata, Physalospora vaccinii, Pestalotia vaccinii, Gloeosporium minus and Discosia artocreas (Vilka et al., 2009).

Fruit rot is the most important problem after cranberry harvest in North America, as it reduces the quality of yield in storage.

Incidence of berry rot during storage has been investigated by researchers in different places and different conditions (Stretch and Ceponis, 1983; Blodgett et al., 2002; Olatinwo et al., 2004; Forney, 2008). Optimal conditions for the storage of fresh cranberry fruit have been investigated for many years in North America (Forney 2008), and it is known that but the amount of decayed berries varies between growing sites and seasons (Olatinwo et al., 2004). In recent years, Olatinwo et al. obtained wide range of incidence of fruit rot in storage from many plantations in Michigan after one month in storage $\left(5^{\circ} \mathrm{C}\right)$; incidence of fruit rot for 'Stevens' varied widely from 5-85\% (2000) and 3-40\% (2001) in different growing sites (Olatinwo et al., 2004). When berries were water harvested and stored at $5{ }^{\circ} \mathrm{C}$, after 7.5 weeks, incidence of fruit rot was $16-52 \%$ (2000). However, in Wis- 
consin, berries, that were harvested by hand and stored at $6{ }^{\circ} \mathrm{C}$, after six weeks incidence of decayed berries was only 4-6\% (Blodgett et al., 2002).

When berries were harvested by wet method, incidence of fruit rot in storage after ten weeks reached $8.5 \%$, compared to $5-6.5 \%$ when harvested by hand in Wisconsin (Stretch and Ceponis, 1983). Hand-picking of berries is an expensive method, but it decreases risk of berry infection by fungi.

Forney (2008) studied the relationships of temperature and humidity on the storage life of fresh cranberry. The effects of storage temperatures from 0 to $7{ }^{\circ} \mathrm{C}$ on marketable fruit after two to five months of storage were not significant and after two months the proportion of decayed berries reached up to $20 \%$. The storage life of cranberry fruit was affected more by storage relative humidity (RH) than by temperature. Optimal humidity conditions for storage was $75-82 \%$ RH (Forey, 2008).

The aim of the study was to investigate the incidence of cranberry fruit rot in storage from different cranberry growing sites in Latvia.

\section{MATERIALS AND METHODS}

Six cranberry plantations in different locations (Talsi, Babīte, Alsunga, Rucava, Ape and Pārgauja municipality) of Latvia (see map, Fig. 1) were surveyed at harvest. Most of the plantations were established after peat extraction with cultivation started between from 1995 (the oldest) and 2002 (the youngest). Only two of the six plantations used fungicides. Fungicide applications were developed based on recommendations in North America and cranberry grower experience from Belarus. More details of the plantations surveyed were described earlier (Vilka and Bankina, 2012). The samples were taken from cultivar 'Stevens'. The observations were carried out in 2007, 2009, 2010, and 2011.

Berries were harvested depending on the ripening time (Table 1) at the six cranberry plantations and the harvest time differed between years.

One hundred sound randomised, medium-sized berries in two replicates (total 200) were sampled from each planta-

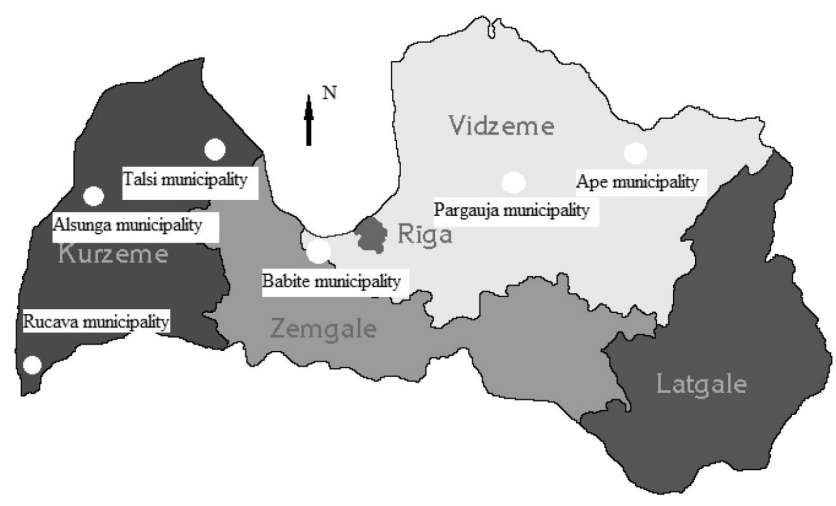

Fig. 1. Surveyed cranberry plantations in Latvia.
Table 1

ASSESSMENT OF CRANBERRY ROT IN STORAGE BY SURVEY YEARS

\begin{tabular}{|c|c|c|c|c|c|}
\hline \multirow{2}{*}{$\begin{array}{c}\text { Year of } \\
\text { assessment }\end{array}$} & \multirow{2}{*}{$\begin{array}{c}\text { Berry } \\
\text { harvest date } \\
\text { in October }\end{array}$} & \multicolumn{4}{|c|}{ Number of days after harvesting } \\
\hline & & \begin{tabular}{|c|}
$1^{\text {st }}$ \\
assessment \\
(end of \\
November)
\end{tabular} & \begin{tabular}{|l}
$2^{\text {nd }}$ \\
assessment \\
(end of \\
December)
\end{tabular} & $\begin{array}{l}3^{\text {rd }} \\
\text { assessment } \\
\text { (end of } \\
\text { January) }\end{array}$ & $\begin{array}{l}4^{\text {th }} \\
\text { assessment } \\
\text { (end of } \\
\text { February) }\end{array}$ \\
\hline 2007 & $13 \pm 4$ days & 48 & 79 & 110 & 138 \\
\hline 2009 & $23 \pm 4$ days & 39 & 70 & 101 & 129 \\
\hline 2010 & $7 \pm 3$ days & 54 & 85 & 116 & 144 \\
\hline 2011 & $4 \pm 2$ days & 57 & 88 & 119 & 147 \\
\hline
\end{tabular}

tion (growing site) and placed in plastic bags (polyethylene, PE-LD 04). Each plastic bag (size $15 \times 22 \mathrm{~cm}$ ) contained 100 berries. The plantations were inspected within a period of a few days (maximum week). Berries were placed in a refrigerator at the same time for fruit rot detection in storage. In each season 1200 berries were evaluated. The same method was used in each year of study. The berries were investigated for a four-month period of refrigeration at $+7{ }^{\circ} \mathrm{C}$, $83 \% \pm 2$ relative humidity. At the end of each month (time depended on harvesting), berries were sorted and rotten berries were separated from the sound ones (Table 1). Decayed fruit were identified by discoloration and softening. They were removed for identification of the causal agent(s) of the storage rot, and the remaining marketable berries were placed back into the refrigerator.

The surface of rotted berries was disinfested in $95 \%$ ethanol solution for 1-2 minutes. With a sterile scalpel, pieces of the berries were placed on potato-dextrose agar (PDA) for causal agent detection. Plates were incubated at $20-25{ }^{\circ} \mathrm{C}$ for three to four weeks (Waller et al., 1998; McManus et al., 2003; Olatinwo et al., 2004). Fungi were identified directly on the isolation plates by comparing morphological characteristics of the spores and spore bearing structures with descriptions in the literature (Caruso and Ramsdell, 1995, at pp. 27-47).

In 2010, excess precipitation persisted for several months (May to September) in comparison with other years. Weather conditions of the growing seasons in 2007, 2009 and 2011 were typical of long-term weather conditions. A considerably higher amount of precipitation was observed in August 2010, when it the long-term average by $190 \%$ and reached $147 \mathrm{~mm}$. The precipitation was particularly high in the Rucava municipality.

The results of the trials were statistically processed with Microsoft Excel for windows and the computer program SPSS 17.0 statistics package. The obtained data were analysed using descriptive statistics, and significance $(P<0.05)$ of the differences between the samples was assessed using single factor ANOVA.

The infection rate of fruit rot was calculated by formula (1), recommended by J. E. Van der Plank (cited by Krantz, 2003). Infection rate describes the speed of changes of dis- 
ease development over time depending on different factors, in this case - period of storage. Infection rate was expressed by condition units of disease units per period of time or for the entire period of disease progress (cited by Krantz, 2003).

$r_{1}=\frac{\ln \left(x_{2}\right)-\ln \left(x_{1}\right)}{t_{2}-t_{1}}$,

$r_{1}-$ rate of infection;

$x_{2}$ - number of rotted fruit in next time of assessment;

$x_{1}-$ number of rotted fruit in previous time of assessment;

$t_{2}-t_{1}-$ number of days between assessments.

\section{RESULTS}

The average incidence of fruit rot from surveyed plantations after one month of storage (end of November) varied from 11 to $35 \%$ depending on year (Fig. 2). After one month of storage, significant differences occurred between years $(P<$ $0.01)$; incidence of fruit rot in 2010 was significantly higher $(35 \%)$ than in other years. Incidence of fruit rot after two months of storage ranged between 24-66\%. Incidence of fruit rot at the end of February in storage on average reached 50-88\%, and significant $(P<0.01)$ differences occurred between years.

The highest infection rates of fruit rot were observed during the first months of storage in all years (Fig. 3). This means that consumer need to process or freeze berries within one month after purchase. The greatest part of Latvian's believe that American cranberry can be stored in the same way as wild cranberry. After two months (47-77 days, end of December) of storage, rate of fruit rot significantly decreased.

For most of the surveyed cranberry growing sites, very rapid increase in the proportion of stored berries with decay was seen after 46 days storage (end of November). The average amounts of decayed berries over survey years did not significantly differ $(P>0.05)$ between the collection sites (Fig. 4). The average incidence of fruit rot at the end of November reached 11-25\% in different growing sites. In 2010, when the amount of decayed berries was very high, incidence of fruit rot at the end of November reached 16-50\% in the growing sites. There was a tendency of higher inci-

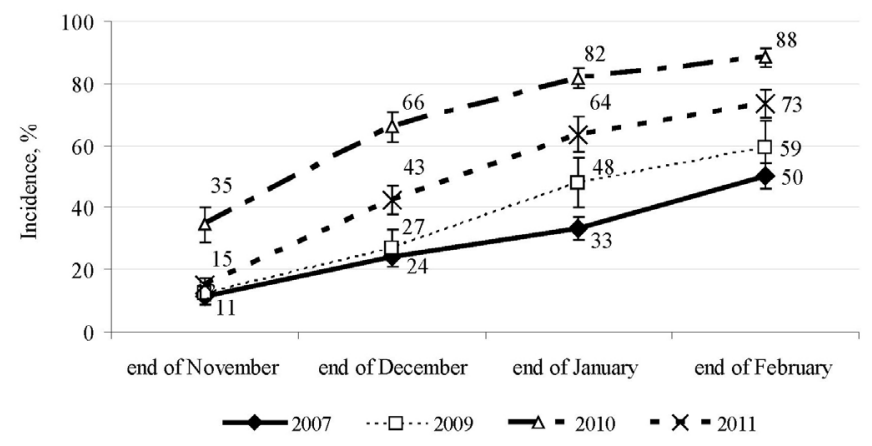

Fig. 2. Dynamics of fruit rot during storage during 2007-2011.

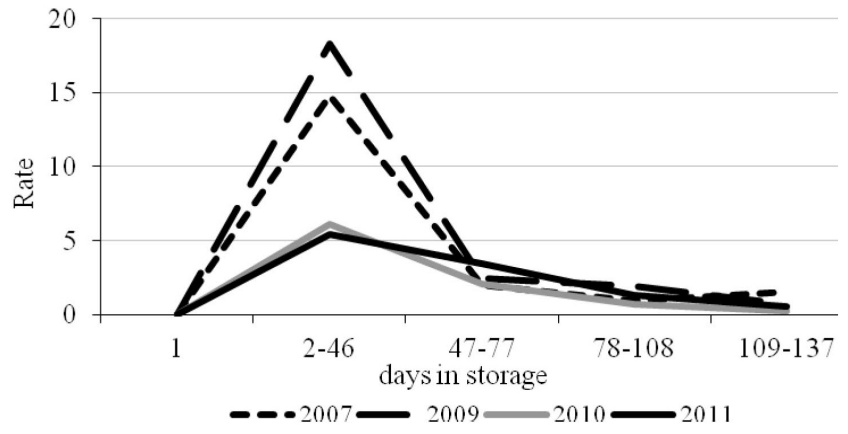

Fig 3. Changes of infection rate during storage depending on year.

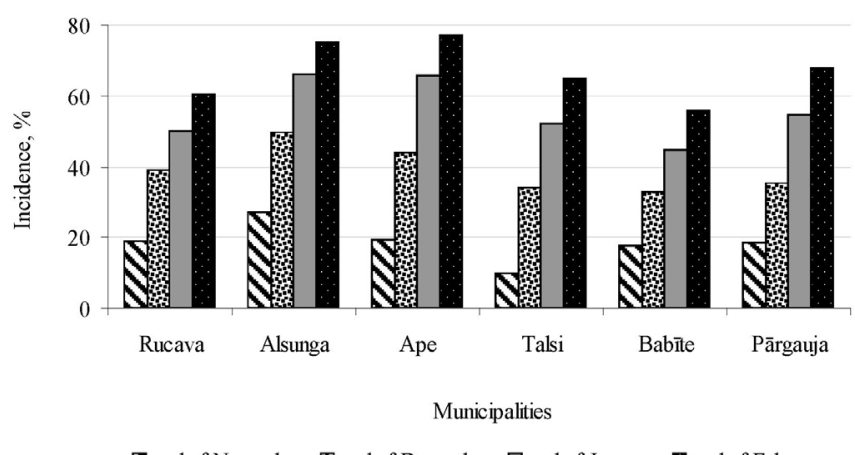

Fig. 4. Average incidence of fruit rot during storage depending on cranberry plantation in Latvia (2007-2011).

dence of fruit rot in the Alsunga municipality every year, which was one of the oldest plantation (since 1995) in Latvia. Significant differences between growing sites were also not observed at the end of February $(P>0.05)$ when average (2007-2011) incidence of fruit rot reached 60-78\%. Only $21.5 \%$ of fresh berries had fruit rot at the end of February in Babīte municipality in 2009 (data were not shown).

Fusiccocum putrefaciens, Coleophoma empetri, Phomopsis vaccinii, Botrytis cinerea, Allantophomopsis cytisporea, Phyllosticta elongata and Physalospora vaccinii were isolated from cranberry fruit rot during the investigation. Incidences of $F$. putrefaciens and $C$. empetri in decayed berries in storage over the study years were higher, compared with other causal agents (Fig. 5). F. putrefaciens and C. emetri were frequent and caused complex fruit rot, but their incidence differed among the cranberry plantations and by years.

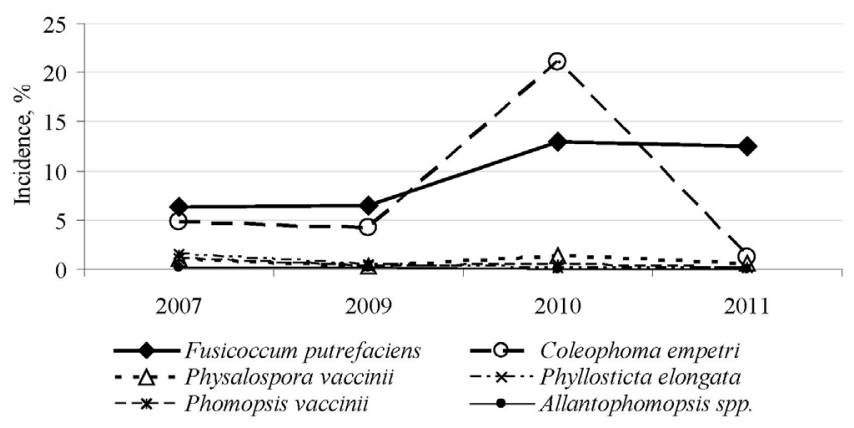

Fig. 5. Dynamics of incidence of causal agent of fruit rot at the end of November in storage during 2007-2011 in Latvia. 


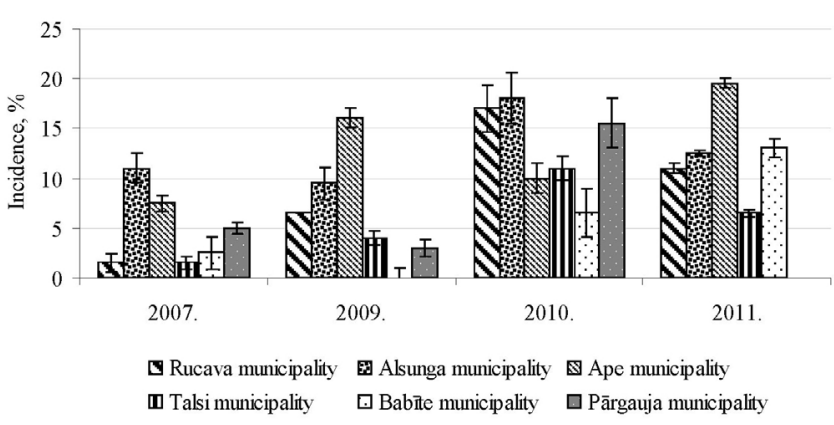

Fig. 6. Incidence of Fusicoccum putrefaciens at the end of November in storage during 2007-2011 by growing site in Latvia.

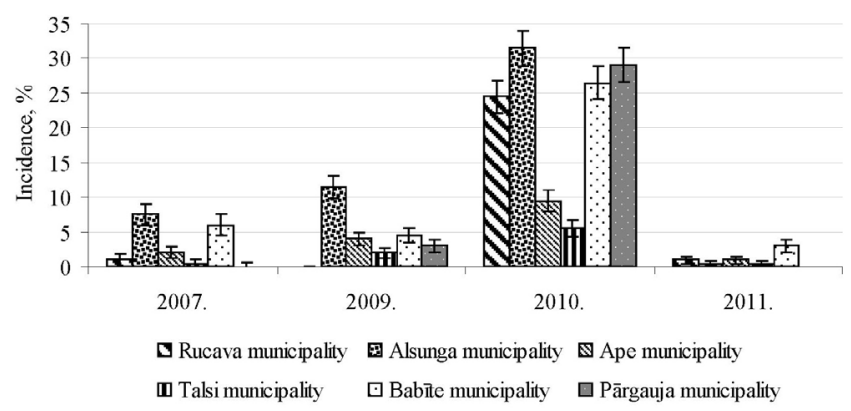

Fig. 7. Incidence of Coleophoma empetri at the end of November in storage during 2007-2011 by growing site in Latvia.

Incidence of $F$. putrefaciens at the end of November in storage among growing sites reached $4.8-13.0 \%$ (average 2007-2011), and there was a trend $(P<0.05)$ of increasing incidence over the years, with very high incidence in 2010 and 2011 in all growing sites (Fig. 6). Differences in incidence of $F$. putrefaciens occurred among growing sites, but were not significant $(P>0.05)$. A relatively high average (2007-2011) incidence of $F$. putrefaciens was observed at the end of November in storage from Alsunga (12.8\%) and Ape $(13.3 \%)$ municipalities, and also in recent years in the Rucava municipality as well. Incidence of $F$. putrefaciens at the end of November from Babīte municipality varied from $0 \%$ (2009) to $13 \%$ (2011), when fruit rot at the end of November in storage reached $4.5 \%$ and $16.5 \%$, respectively.

Incidence of $C$. empetri varied between years and growing sites in Latvia. Incidence of $C$. empetri at the end of November in storage reached 1.2-21.0\% among growing sites (average 2007-2011), and significant differences $(P<$ 0.001 ) occurred between very high incidence (6-32\%) of C. empetri was observed in 2010 in all growing sites, compared with other years (Fig. 7). However, in 2011 the incidence of $C$. empetri in storage (end of November) had declined and reached only $0.5-3.0 \%$ in the growing sites $(P>$ $0.05)$. There was a tendency of higher $(0.5-32 \%)$ incidence of $C$. empetri in the oldest cranberry growing site (Alsunga municipality) and the lowest $(0.5-6.0 \%)$ in the youngest growing site (Babīte municipality).

\section{DISCUSSION}

In Latvia, for fresh fruit marketing, cranberries are stored at $2-4{ }^{\circ} \mathrm{C}$ in a refrigerator, whereas most of the customers store berries at $+7{ }^{\circ} \mathrm{C}$ for consumption of fresh fruit. Fruit rot is an important problem during storage. Cranberry rot is a disease complex that can be caused by several pathogens. We have found the same pathogens as those reported in North America (Gourley, 1979; Caruso and Ramsdell, 1995; McManus et al., 2003; Olatinwo et al., 2004). The incidence of fruit rot fungi varied by years and among surveyed plantations in Latvia. In North America, F. putrefaciens is common in northern regions and $C$. empetri in southern regions of (Olatinwo et al., 2004) In Latvia both are common, and the geographical location of cranberry growing sites was not significant.

Storage rot was a significant problem in cranberry samples from all inspected growing sites in Latvia. This problem is important in all cranberry growing sites in North America also (Gourley, 1979; Olatinwo et al., 2004).

Trends of fruit rot development were similar in all years of investigation, but the high level of fruit rot incidence in 2010 probably was caused by the weather conditions in the vegetation season.

After 54 days (eight weeks) of storage, incidence of fruit rot in 2010 in Latvia (16-50\%) was near the incidence level after 7.5 weeks of storage in Wisconsin (16.2-50\%) in 2000 (Blodgett et al., 2002). This suggests that the situation is similar in the two different continents.

The most critical period of berry storage is the first two months, when a high infection rate occurs. During this period, on average about one half of all berries were decayed and thus storage for longer than this time is economically disadvantageous.

To be economically profitable, at normal conditions in a refrigerator, cranberries can be stored as fresh fruit for a month or two in Latvia and North America (Forney, 2003; Olatinwo et al., 2004). It is possible that the storage time of cranberries is short, because most berries become infected during the season, with fruit rot becoming apparent in storage.

Fruit rot is important problem in all plantations of cranberry in Latvia. A wide range of incidence of fruit rot (16.5-50\%) in different locations in Latvia was observed at the beginning of storage in 2010, in comparison with other years. At the end of storage, a wide range of incidence of fruit rot (21-78\%) occurred in 2009, indicating that the amount of decayed berries differs substantially among cranberry growing locations in Latvia. Urgent fruit processing after harvest is necessary in Alsunga municipality, as in recent years, incidence of fruit rot after one month of storage reached $13-50 \%$ and thus storage is not economically profitable.

\section{ACKNOWLEDGEMENTS}

This study was supported by the Ministry of Agriculture of Latvia "Specification of environment-friendly technologies in fruit and berry plantations in different soil, and climatic 
conditions" in 2007-2009 and "Sustainable development of fruit growing, using environment-friendly and water saving, as well as the rural landscape retaining integrated production technologies to reduce climate changes and to maintain biodiversity" in 2010-2012.

\section{REFERENCES}

Blodgett, A. B., Caldwell, R. W., McManus P. S. (2002). Effects of calcium salts on the cranberry fruit rot disease complex. Plant Dis., 86, 747-752.

Caruso F. L., Ramsdell D. C. (eds.) (1995). Cranberry Diseases Compendium of Blueberry and Cranberry Diseases. St. Paul, MN: APS Press. $87 \mathrm{pp}$.

Forney, C. F. (2003). Postharvest handling and storage of fresh cranberries. HortTechnol., 13 (2), 267-272.

Forney, C. F. (2008). Optimizing the storage temperatureand humidity for fresh cranberries: A reassessment of chilling sensitivity. HortSci., 43 (2), 439-446.

Gourley, C. O. (1979). Further observations on cranberry fungi in Nova Scotia. Can. Plant Dis. Surv., 59 (1), 15-17.

Kranz, J. (2003). Comparative Epidemiology of Plant Diseases. Springer. 206 pp.

Received 21 March 2013
McManus, P. S., Caldwell, R. W., Voland, R. P., Best, V. M., Clayton, M. K. (2003). Evaluation of sampling strategies for determining incidence of cranberry fruit rot and fruit rot fungi. Plant Dis., 87, 585-590.

Olatinwo, R. O., Schilder, A. M. C., Kravchenko, A. N. (2004). Incidence and causes of postharvest fruit rot in stored Michigan cranberries. Plant Dis., 88 (11), 1277-1282.

Stretch, A. W., Ceponis, M. J. (1983). Influence of water immersion time and storage period on black rot development in cold-stored, water-harvested cranberries. Plant Dis., 67, 21-23.

Vilka, L., Bankina, B. (2012). Incidence of postharvest rot of cranberry (Vaccinium macrocarpon Ait.) in Latvia. In print: Research for Rural Development 2012. $18^{\text {th }}$ annual international scientific conference proceedings.

Vilka L., Rancane R., Eihe M. (2009a). Fungal diseases of Vaccinium macrocarpon in Latvia. Latv. J. Agron.[Agron. Vēstis], 12, 125-133 (in Latvian).

Vilka, L., Rancane, R., Eihe, M. (2009b). Storage rots of Vaccinium macrocarpon spread and development in Latvia. Latv. J. Agron. [Agron. Vēstis], 12, 133-137 (in Latvian).

Waller, J. M., Ritchie, B. J., Holderness, M. (1998). Plant Clinic Handbook. International Mycological Institute Technical Handbooks, Vol. 3. CAB International, UK. 94 pp.

\section{LIELOGU DZĒRVEN̦U (Vaccinium macrocarpon Ait.) OGU PUVES IZPLATĪBA GLABĀŠANAS LAIKĀ LATVIJĀ}

Lielogu dzērvenes (Vaccinium macrocarpon Ait.) ir pieprasītas gan Latvijas, gan ārvalstu tirgū, līdz ar to ir iespēja attīstīt lielražošanu, taču lielas problēmas rada ogu puve glabāšanas laikā. Pētījuma mērḳis bija noteikt lielogu dzērveṇu ogu puves attīstības dinamiku glabāšanas laikā dažādās Latvijas vietās. No 2007. gada līdz 2011. gadam ražas laikā tika ievāktas 200 nebojātas ogas (kopā 1200) randomizēti izvēlētās vietās sešos dažādos lielogu dzērven̨u stādījumos Latvijā. Ogas tika uzglabātas plastmasas maisin̨os un turētas četrus mēnešus +7 ${ }^{\circ} \mathrm{C}$ vēsā kamerā. Katra mēneša beigās ogas pārlasītas, atškirojot no veselām puves bojātās. Pētījuma laikā noskaidrots, ka lielogu dzērvenes var uzglabāt tikai vienu līdz divus mēnešus, jo ogu puve šajā laikā jau sasniedza 18-21\%. Savukārt līdz februāra beigām puves izplatība jau sasniedza 50-88\%. 2010. gada nokrišniem bagātā vasara būtiski ietekmēja ogu kvalitāti glabāšanas laikā, bet kopumā var novērot tendenci katru gadu ogu puves izplatībai palielināties glabāšanas laikā. No puves bojātām ogām izolēti vairāki patogēni: Fusiccocum putrefaciens, Coleophoma empetri, Phomopsis vaccinii, Botrytis cinerea, Allantophomopsis cytisporea, Phyllosticta elongata un Physalospora vaccinii, no kuriem galvenokārt izplatīti bija $F$. putrefaciens un $C$. empetri. Novērots, ka apsekotajos lielogu dzērvenuu stādījumos atškīrās ogu puves un to ierosinātāju izplatība glabāšanas laikā un turpmāk tā var sagādāt lielākus zaudējumus, jo ar katru gadu ogu puves izplatība pieaugs. 